\title{
Northernmost record of Hacelia attenuata (Echinodermata: Asteroidea) in the Atlantic
}

Nuno Vasco-Rodrigues ${ }^{1,2,3}$

\begin{abstract}
Background: The seastar Hacelia attenuata is present in the Mediterranean but also in the Azores, Madeira, Canary Islands, Cape Verde and Gulf of Guinea.

Methods: While scuba diving in Berlengas Archipelago (Peniche, Portugal), the author observed two individuals of this species.

Results: This expands its geographic distributions and represents the northernmost record of this species in the Atlantic.

Conclusion: Geographic boundaries of species are changing on a daily basis and it is crucial to report these new occurrences and to keep monitoring species distribution and biodynamic, in order to predict future changes.
\end{abstract}

Keywords: Seastar, Ophidiasteridae, Geographic range, Berlengas archipelago, Climate change

\section{Background}

The growing global pressures on the collection of echinoderms for various commercial enterprises have put these enigmatic invertebrates under threat (Micael et al. 2009). Considering that some echinoderm species are important in determining habitat structure for other species and can represent a substantial portion of the ecosystem biomass (Micael et al. 2011), new information on species biology and respective geographic distribution boundaries is crucial to better understand the role played by these organisms in the ecosystem.

The smooth seastar Hacelia attenuata Gray, 1840 is relatively common in the Mediterranean Sea occurring also in the Azores (Micael et al. 2012), Canary Islands, Cape Verde, Gulf of Guinea (Hansson 1999; Wirtz and Debelius 2003) and Madeira (Espino et al. 2006). PérezRuzafa and Lopez-Ibor (1987) also reported this species for an area which the authors called "Portugal", however, this area comprised not just the western and south coast of Portugal but also the gulf of Cadiz (Spain). More recently, it was confirmed to occur in the Gulf of Cadiz

Correspondence: nunovascorodrigues@gmail.com

${ }^{1}$ MARE - Marine and Environmental Sciences Centre, ESTM, Polytechnic Institute of Leiria, 2520-641 Peniche, Portugal

${ }^{2}$ Flying Sharks, Rua Jorge Castilho 1613, 7C - 1900-272 Lisbon, Portugal

Full list of author information is available at the end of the article
(Rueda et al. 2011) and also in the Gorringe seamount (OCEANA 2014).

The species is uniformly orange to red (Rueda et al. 2011) and is characterized by having five cylindrical arms - provided by numerous protuberancesa on the aboral zone - linked by a broad base to a small disk (Bergbauer and Humberg 2000).

It is reported to occur at dephts between $1 \mathrm{~m}$ and $150 \mathrm{~m}$ (Hansson 1999) but is more common below $20 \mathrm{~m}$ depth (Espino et al. 2006; Wirtz and Debelius 2003) preferably in areas with low light intensity (Bergbauer and Humberg 2000; Espino et al. 2006).

Like many related species, it has been targeted for ornamental reasons by the aquarium industry (Espino et al. 2006). Two specimens were observed at Berlengas Archipelago and a photographic register was made for one of them. Subsequent identification and bibliographic research confirmed this as a new northernmost record for this species in the Atlantic Ocean.

\section{Results}

Two specimens of Hacelia attenuata were observed in Berlengas Archipelago. Both individuals found were adults with approximately $20 \mathrm{~cm}$ in diameter.

One of the specimens was photographed side by side with a red seastar Echinaster sepositus (Fig. 1). 


\section{Systematics}

Class ASTEROIDEA de Blainville, 1830

Order VALVATIDA Perrier, 1884

Family OPHIDIASTERIDAE Verrill, 1870

Genus HACELIA Gray, 1840

Hacelia attenuata Gray, 1840

(Fig. 1)

\section{Discussion}

The presence of Hacelia attenuata at Berlengas, extends its known northern geographical range in the Atlantic, with literature referring the Azores Islands as its previous northernmost limit (Hansson 1999; Wirtz and Debelius 2003). Rueda et al. (2011) also reported its presence in the Gulf of Cadiz (Spain), although this is an area strongly influenced by the Mediterranean ecosystem (Coll et al. 2014), where it is known to be common (Wirtz and Debelius 2003).

Hacelia attenuata presents a similar reddish coloration and reaches approximately the same diameter as the red seastar Echinaster sepositus but also the purple seastar Ophidiaster ophidianus (Lamarck, 1816) and Hacelia superba H.L. Clark, 1921 which led to some misidentifications in the past (Nobre 1938; Rueda et al. 2011), and may raise doubts on its real distribution.

Unlike Ophidiaster ophidianus and Hacelia superba, which do not occur in this area, the red seastar E. sepositus is relatively common in Berlengas (Rodrigues et al. 2008) - occurs from Roscoff (France) to Ghana, including island groups except Azores and also in the Mediterranean (Wirtz and Debelius 2003) - and one specimen was also found when these underwater records were made. Both species were photographed side by side and differences are notorious (Fig. 1). The coloration of $H$. attenuata is more yellowish than E. sepositus and, although is not very clear in the photo, the aboral pattern and texture is distinctively different. The presence of $H$.

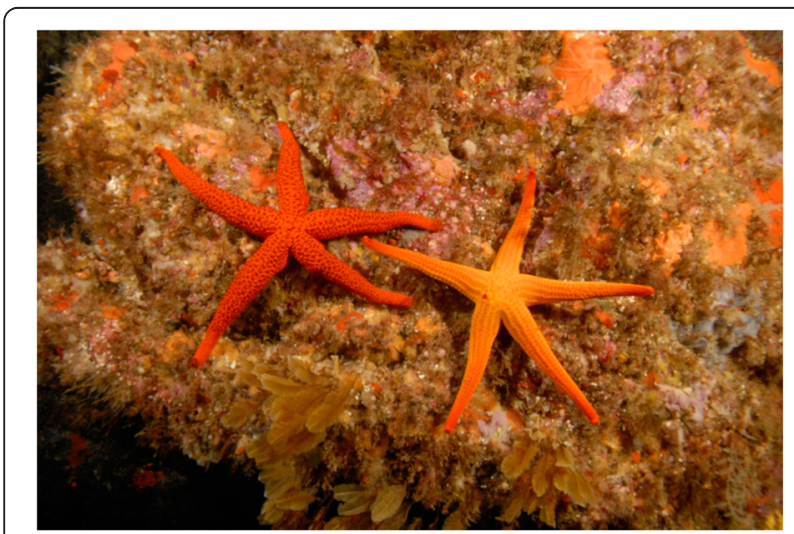

Fig. 1 Red seastar, Echinaster sepositus (left) and smooth seastar, Hacelia attenuata (right) attenuata in Berlengas represents also the first record of a species of the Ophidiasteridae family for the region.

The Berlengas archipelago is located at the top of the escarpment of the Nazaré Canyon, an important submarine canyon in the transition zone between the Mediterranean and European subregions (Mendes et al. 2011). It is influenced by coastal upwelling (ÁlvarezSalgado et al. 2003; Peliz et al. 2002) and characterized by a remarkable productivity and diversity of marine species and habitats (Rodrigues et al. 2008). These factors may lead to the settlement of non-local species that reach the area and manage to thrive (e.g. larvae driven by oceanic currents, ballast waters). Rodrigues (2012) reported various new species records for the area, most of which new northernmost records. Global warming is one possible reason for driving tropical and sub-tropical species to migrate to regions where previous climate was not warm enough (Afonso et al. 2013). However, the same author, recorded new southernmost limits for other species in the same study area, suggesting that this may also reflect the reduced number of underwater surveys when compared to other places worldwide. Surveys from the Mediterranean to Berlengas area would help clarifying the presence of this species in latitudes where it was not known to occur until now.

\section{Conclusions}

In a time where geographic distribution boundaries of species are being redesigned almost every day (Abecasis et al. 2006; González-Wangüemert and Borrero-Pérez 2012), and major faunal changes are more and more probable, the Portuguese shore will be one of Europe's best places to investigate and predict the course of ecological perturbations, due to its transitional nature (Almada et al. 2001).

It is, therefore, crucial to develop more studies in this area, to register these new occurrences and to keep monitoring species distribution and biodynamic, in order to predict future changes and to act accordingly, while ensuring the species survival and sustainability.

\section{Methods}

The records of Hacelia atenuata here reported were done using underwater photography while scuba diving in Berlengas Archipelago (N 39 28', W 9 32') (offshore Peniche, West of Portugal), at approximately $20 \mathrm{~m}$ depth. Both animals were foraging on the top of an irregular rocky reef - mostly covered by sessile biota including algae, sponges, hydrozoans, anemones and bryozoans - separated about $200 \mathrm{~m}$ from each other, at moderately exposed sites. 


\section{Competing interests}

The author declares that he/she has no competing interests.

\section{Acknowledgements}

The author would like to thank José Alberto and Haliotis Dive Center for the support given during the dives and sampling procedures; Dora Jesus for providing information on the species and literature; José Gomes-Pereira for comments and suggestions to this ms.

\section{Author details}

${ }^{1}$ MARE - Marine and Environmental Sciences Centre, ESTM, Polytechnic Institute of Leiria, 2520-641 Peniche, Portugal. Flying Sharks, Rua Jorge Castilho 1613, 7C - 1900-272 Lisbon, Portugal. ${ }^{3}$ Task Group for the Extension of the Continental Shelf, EMEPC, Paço de Arcos, Portugal.

\section{Received: 10 February 2016 Accepted: 23 February 2016}

Published online: 22 March 2016

\section{References}

Abecasis D, Bentes L, Ribeiro J, Machado D, Oliveira F, Veiga P, et al. First record of the Mediterranean parrotfish, Sparisoma cretense in Ria Formosa (south Portugal). Mar Biodiv Rec. 2006;1:e27.

Afonso P, Porteiro F, Fontes J, Tempera F, Morato T, Cardigos F, et al. New and rare coastal fishes in the Azores islands: occasional events or tropicalization process? J Fish Biol. 2013;83(2):272-94.

Almada V, Henriques M, Gonçalves $\mathrm{E}$. The study of inshore fishes in Portugal - a brief history and prospects for the future. 2001.

Álvarez-Salgado XA, Figueiras FG, Pérez FF, Groom S, Nogueira E, Borges AV, et al. The Portugal coastal counter current off NW Spain: new insights on its biogeochemical variability. Prog Oceanogr. 2003;56:281-321.

Bergbauer M, Humberg B. La vie sous-marine en Mediterranée. Paris: Éditions Vigot; 2000

Coll M, Carreras M, Ciércoles C, Cornax MJ, Gorelli G, Morote E, Saez R. Assessing fishing and marine biodiversity changes using fishersé perceptions: the Spanish Mediterranean and Gulf of Cadiz case study. PLoS ONE. 2014;9(1) doi: 10.1371/journal.pone.0085670.

Espino F, Boyra A, Tuya F, Haroun R. Guia Visual de Especies Marinas de Canarias. Grand Canaria: Oceanográfica Divulgacíon, Educación y Ciencia S.L; 2006.

González-Wangüemert M, Borrero-Pérez G. A new record of Holothuria arguinensis colonizing the Mediterranean Sea. Mar Biodiv Rec. 2012;5:e105. doi:10.1017/S1755267212000887.

Hansson HG. European Echinodermata check-list - a draft for the European Register of Marine Species. 1999

Mendes S, Marques SC, Azeiteiro UM, Fernandez-Gomez MJ, Galindo Villardon MP, Maranhão P, et al. Zooplankton distribution in a Marine Protected Area: the Berlengas Natural Reserve (Western coast of Portugal). Fresenius Environ Bull. 2011;20(2):496-505

Micael J, Alves MJ, Costa AC, Jones MB. Exploitation and conservation of echinoderms. Oceanogr Mar Biol Annu Rev. 2009;47:191-208.

Micael J, Rodrigues AS, Barreto MC, Alves MJ, Jones MB, Costa AC. Allocation of nutrients during the reproductive cycle of Ophidiaster ophidianus (Echinodermata: Asteroidea). Invertebr Reprod Dev. 2011;55:205-16. doi:10.1080/00207233.2011.573673.

Micael J, Alves MJ, Jones MB, Costa AC. Diversity of shallow-water asteroids (Echinodermata) in the Azorean Archipelago. Mar Biodiv Rec. 2012;5, e49. doi:10.1017/S1755267211000534

Nobre A. Echinodermes de Portugal. 2a Edição. Porto; 1938.

OCEANA, Stiftung Drittes Millenium. The Seamounts of the Gorringe Bank. 2014 p. 38.

Peliz A, Rosa T, Santos AMP, Pissarra J. Fronts, jets, eddies and counterflows in the western Iberia upwelling system. J Mar Syst. 2002;35:61-77.

Pérez-Ruzafa A, Lopez-Ibor A. Echinoderm fauna from south-western Mediterranean. Biogeographic relationships. In: Burke RD, Mladenov PV, Lambert P, Parsley RL, editors. Echinoderm Biology. Rotterdam: A.A. Balkema; 1987. p. 355-62.

Rodrigues NV. New geographic distribution records for Northeastern Atlantic species. Arquipélago Life Mar Sci. 2012;29:63-6.
Rodrigues NV, Maranhão P, Oliveira P, Alberto J. Guia de Espécies Submarinas Portugal - Berlengas. Leiria: Instituto Politécnico de Leiria; 2008.

Rueda JL, Gil J, González-García E, Farias C, López-González N, Díaz-del-Río V. First record of Hacelia superba (Echinodermata: Asteroidea) on the European continental margin. Mar Biodiv Rec. 2011;4:1-5.

Wirtz P, Debelius H. Mediterranean and Atlantic Invertebrate Guide. Hackenheim: Conchbooks; 2003

\section{Submit your next manuscript to BioMed Central and we will help you at every step:}

- We accept pre-submission inquiries

- Our selector tool helps you to find the most relevant journal

- We provide round the clock customer support

- Convenient online submission

- Thorough peer review

- Inclusion in PubMed and all major indexing services

- Maximum visibility for your research

Submit your manuscript at www.biomedcentral.com/submit 